\title{
URBAN ROOFSCAPES IN TRANSITION - THE CASE OF GRAZIAUSTRIA
}

\author{
Walter Zsilincsar \\ University of Graz, Institute of Geography and Regional Science, \\ Heinrichstraße 36, A-8010 Graz \\ e-mail: geographie@uni-graz.at
}

\begin{abstract}
By the example of the Austrian city of Graz whose old town has been declared a world heritage site in 2000 attention shall be focused on the more or less "unnoticed" changes of the historic roofscape that can be observed and that should attract more interest from a geographical (creation of new living space, attraction of new social groups to the city-center), planning and urban zoning (redevelopment of the building and functional structures) or architectonic (urban conservation) perspective.
\end{abstract}

Key words: Roofscape, cultural heritage, conservation, roofing material, transformation, dormer window, roof truss

\section{INTRODUCTION}

Different types and forms of roofs are not only a determining feature of architecture but also of cultural traditions, climatic conditions, regional availability of building materials, different uses and religious or spiritual conceptions. Thus clear regional differences and types of cultural landscapes can be observed.

This contribution focuses on the specific roofscape of the historic center of the city of Graz which was one essential architectonic reason to consider Graz as a UNESCO worldcultural-heritage-site in 1999. It, moreover, played a role in the publicity campaign for "Graz 2003, cultural capital of Europe" although the area of the medieval town including the castle hill (Schloßberg) covers merely a little more than $1 \%$ of the present total urban surface of 12.726 ha.

The term "roofscape" which among some puristic geographers has evoked displeasure in the past can be used and interpreted in various ways: geographically, (art-)historically, ecologically, functionally, aesthetically, sociologically, urbanistically. It must be noted, however, that the paper presented is a preliminary survey only of a larger investigation which will be executed in cooperation with the urban planning board of the city of Graz. 
In evaluating the architectonic and aesthetic character of a roofscape one has to consider two different kinds of possible views: a ground-borne and an air-borne (from an elevated position) one. Being looked at from the air a town reconciles a completely different image. Roads, places, parks, gardens, backyards, rivers and other open water spaces assume new or other forms and dimensions. Connexions, relationships and functions become visible and comprehensible much more. The different stages of urban development disclose themselves before the spectator.

However, the situation is not always that clear as it may seem. Buildings, namely their roadsided facades often have been subject to changes (renovations, new paints, windows, or doors) whereas roofs until the second half of the last century did not suffer from changes that frequently and, sometimes, that substantially.

During the recent past a new development can be observed not only in big but also in smaller cities and towns which has got various reasons: the transformation of roofspaces from their original usages as a mere form of protection of the house from atmospheric inclemencies, as simple smoke-drains, or as storage spaces and drying-rooms into living spaces not for the underprivileged but for a new clientel of well-off citizens who prefer and can afford living "over the roofs" of their home towns.

The backgrounds for this development are manifold: the severely reduced supply with well-equipped flats in inner-urban districts which very often offers only few alternatives like the expansion of attic apartments, the efforts of the communities to make living in the city-cores more attractive, time consuming and stressing daily commuting between suburban homes and inner-urban working places, and new trends of living or life-styles at the turn of the century in general.

\section{THE ROOFSCAPE OF THE HISTORIC CENTER OF GRAZ- LEGISLATIVE COMPETENCES}

A specific feature of the roofscape of Graz is its round-about visibility from the castle hill, a dolomite rock and erosional outlier of the Graz Paleozoic which had borne a small Slovene fortification in the early middle ages, one of the germ cells of the later urban development.

The good condition and extraordinary architectonic quality of the historic center of Graz despite the fact that Graz was one of the heaviest bombed Austrian towns during the Second World War as well as the dangers which have threatened the historic building substance as a consequence of post-war economic awakening gave rise to a number of politicians, scientists, architects and citizens with a high sense of duty for the inherited cultural monuments and signs of the past to struggle for their conservation and future protection. Finally, in 1974, reinacted in 1980, the "Grazer Altstadterhaltungsgesetz" (Law for the Conservation of the Historic Center of Graz) was issued.

In his introductionary remarks to this law the late vice-governour of Styria Dr. Kurt Jungwirth wrote analogously referring to the dangers mentioned above: what man had failed to destroy during the war he succeeded in demolishing and disfiguring during the following decades of peace. The temptation to let buildings decay for mere speculation's 
sake was simply too big. Perhaps it was not speculation, illiteracy, lack of historic consciousness alone that was responsible for the destruction of many historic single objects or ensembles. It may well be that through destroying signs of the past (especially those buildings bearing visible war damages) people tried to forget about that dark chapter of their history and that by constructing a new built environment they wanted to express confidence in a stable future, social and economic progress.

Those persons that had opposed this scenario were by no means conservative backwoodsmen, they simply felt responsible for their common architectonic heritage. They claimed respect and reverence for the precious relics of our culture without neglecting the necessity of progress and further development. The main criterion for evaluating architectonic signs of both past and future should always be quality. But, who is guarding the holy grail of architectonic quality?

The Styrian provincial government has installed a commission of experts (Sachverständigenkommission). In case of violations of the (Styrian) building order or the Law for the Conservation of the Historic Center of Graz the commission is entitled to report to the building authority. Furthermore the commission proposes financial aid to single objectowners, renders expertises as to all building measures and changes of utilization within the protection zones (cf. Mally, K.H. und H. Widtmann, 1986).

In particular the commission has to express its opinion about the following cases:

- grants for remedying of earlier deformities of protected buildings

- grants for changes of utilization of distinct objects within the protection zone

- $\quad$ building permits for construction works on public spaces

- $\quad$ applications to stop building activities and changes of utilization without agreement

- orders to dismantle objects without a building permit and to reconstruct those that have been demolished without notice of approval

- granting or rejection of promotional subsidies

- furthermore the Commission for the Conservation of the Historic Center of Graz furnishes expertises concerning the dedication of development sites and building or demolition permits within the protected area.

The area of protection as proclaimed by the above law comprises of five separate zones (Fig. 1). This paper concentrates mainly on the two inner zones which more or less cover the city's medieval core and early suburban developments.

\section{THE HISTORY OF THE GRAZ ROOFSCAPE}

Recent archaeological excavations in the central parts of Graz have brought about completely new insights into the settlement structure of the city during the early middle ages. The coverage type of the early medieval town revealed a closed settlement where later on a huge triangular market square (today's main square = Hauptplatz with the town hall at one side) formed and still forms the center of the burgher city. This densely built up village or market-town existed until the $14^{\text {th }}$ cent. Afterwards the area close by the river Mur and the 
castle-hill with its small fortress ("gradec") must have been razed to create open space for a market which probably also profited from the nearby ford or bridge across the river.

Still older than this town was a village in close vicinity to a castle that apart from the early fortress on the castle hill has been built on a higher terrasse of the Mur and dates back to around the year 1000. Some remnants of wooden houses from this period have been excavated in 2002.

Figure 1: Zones of architectonic protection in Graz (Source: Ch. Müller, 2002)

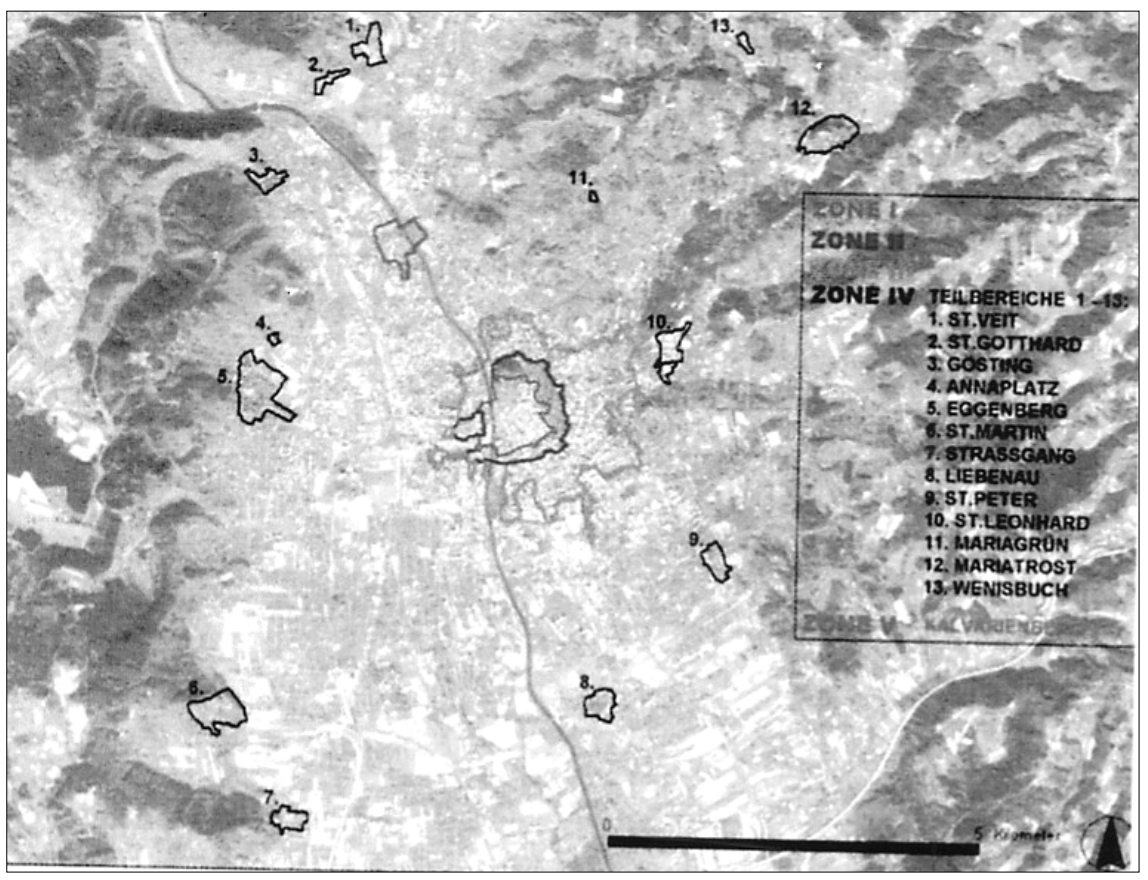

Today's urban ground-design of the city center, therefore, is the result of several stages of development which still can be traced back also from the various forms, types, sizes and materials of roofs and roof-covering. So, the bird's-eye on the roofs of a town can tell a lot about the social, economic, functional, or technological changes which had allowed this development to take place.

As other medieval cities Graz was located at a point which not only guaranteed utmost protection from enemies (castle hill, river Mur) and from floods (existence of river terrasses) but also great accessibility (good place for constructing a bridge over the river), and ample space for performing agriculture and for urban expansion.

The historic growth plan of Graz from the early $12^{\text {th }}$ until the $17^{\text {th }}$ cent. shows the different stages of urban expansion. The agrarian structure of the first rural-urban community has not left any visible traces apart from some recent excavations, and surface areas of early buildings and real property. Some long-stretched narrow lots along the Sackstraße, Spor- 
gasse and Hauptplatz point to their possible agrarian or semi-agrarian function during the middle-ages.

Certain characteristics of roof-forms allow us to conclude about the period of their construction and matter of style. Steep and narrow gabled roofs with full-, semi-, or quarter hips are typical for gothic-medieval town houses. The initial wooden shingle-roofs later on have been replaced by flat roofing clay tiles ("Biberschwanz") because of the steady danger of fire which was further raised by the usage of the roof floor for storage purposes. Small garret windows and skylights on many roofs proof this function. Houses which had been directed towards roads and places with their troughs either belonged to wealthier citizens who could afford bigger lots or they resulted from a subsequent fusion of neighbouring lots. A typical attribute of gothic burghers' houses are various forms of alcoves and bay-windows.

Trench roofs have been developed during the baroque. For lighting and ventilation of the loft frequently oval windows ("Ochsenaugen") have been used. Blind gables sometimes hide the trench roofs to reconcile the impression of a wider through-side. In the baroque also the mansard-roof was invented. It was still popular during the classicist époque and has survived until our days. It appears in several modifications as mansard-gable roof, as mansard-(semi-) hip-roof, etc. A specific reminiscence of baroque chinoisery can be found in some rare examples of hipped tin-covered mansard roofs.

From the classicist period onward and especially during the founders' period the former steep gabled roofs became smoother with inclinations less than $45^{\circ}$. Attics, cupolas, domes, and various ornamental elements now shape facades and roofs. Especially the corners of buildings are being architectonically brought into prominence by alcoves, small domes, and turrets (Fig. 6). New (modern) solutions for the roof corners mainly of buildings from the second half of the $19^{\text {th }}$ cent. until World War II will be presented later. They result from adaptation works of hitherto unused roof space for living purposes.

Despite the high degree of protection the historic center benefits we can also find some examples of (late) $20^{\text {th }}$ cent. architecture and roof-solutions there (Fig. 2) (cf. Breitling, P., 1982). Nevertheless, if we argue about the architectonic quality and beauty of a town in most cases it goes without saying that we refer to its historic core. May be that in the recent past only a new dimension of urban identification is gaining some importance, that of mega-shopping-malls on the outskirts.

\section{ROOFING MATERIALS}

Roofing materials have always been subject to different uses, architectonic purposes, functions, social, economic, and aesthetic considerations. So, to some extent, they can tell us a lot about their historic background, that of the building they protect, and, sometimes, even of whole quarters or towns.

There is not much evidence of original roofing materials that had been used by the first medieval dwellers of Graz. From archaeological excavations mentioned before we know, however, that wood had been the farthest-spread building material. It can be con- 
cluded, therefore, that apart from rye-straw, wooden tiles had covered the early roofs. In the course of the economic, social and legal consolidation of the early settlement and due to the steady danger of fire-damage wood as a building and roofing material has been gradually replaced by stone, or bricks, and clay tiles or tin-plates namely for hats of church towers.

Figure 2: Graz, Glacisstrasse. Construction of a new roof-dwelling on a late-baroque suburban house

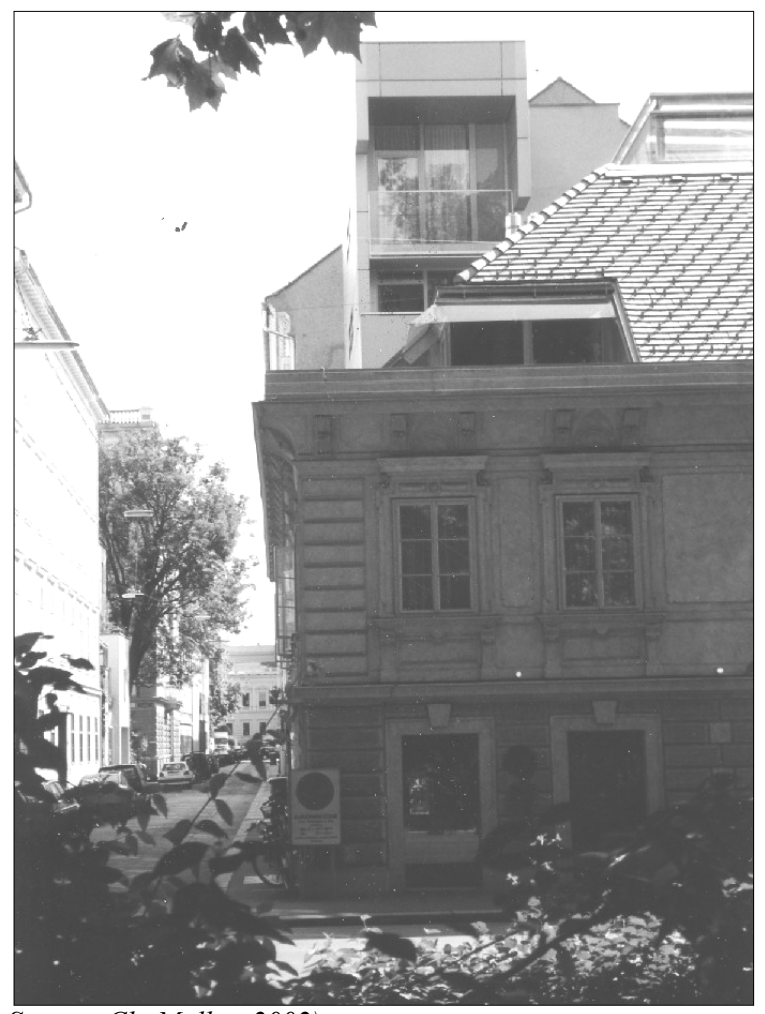

Source: Ch. Müller, 2002).

These traditional materials are distinguished by a visible aging process, that bestows a patina upon the roofs which many modern tiles made of cement, asbestos, or metal are missing. Their impression is steril and inanimate in opposition to ancient flat roofing-tiles. The Commission for the Conservation of the Historic Center of Graz insists on the retention of red clay tiles and financially supports the further usage of old flat roofing tiles, wherever possible.

When in 1843 C. Schreiner (1976) had published a comprehensive and very informative "topographic and statistical description" of Graz and her suburbs the then existing roofscape was no topic of special interest. There can be found only some rare and short hints as to forms and materials of roofs in his book. The demolished former connecting passage between the imperial castle and the cathedral is being described bearing "a simple 
slender tiled roof". The "Landhaus" (assembly of the estates) is said to dispose of a steep roof with coloured and glazed tiles and a little clock-tower. Other remarks concern the shape of churchtowers and the decoration of single gables.

From Schreiner's portrayal and additional drawings of various suburban landscapes of Graz, especially when viewed from elevated observation posts, we can get quite good an impression of the smooth roofscape of the former suburban villages and their harmonious integration into the surrounding (semi-)rural ambient (Fig. 3). Additional noteworthy architectonic elements were the first industrial buildings like paper-, saw- and grain mills, tanneries, nail-forges, button factories, as well as monestaries, hospitals and barracks. Many of them still exist as buildings although their function and architectonic position has changed.

Figure 3: Graz. The „, Graben“ suburb as seen from the castle hill in 1843

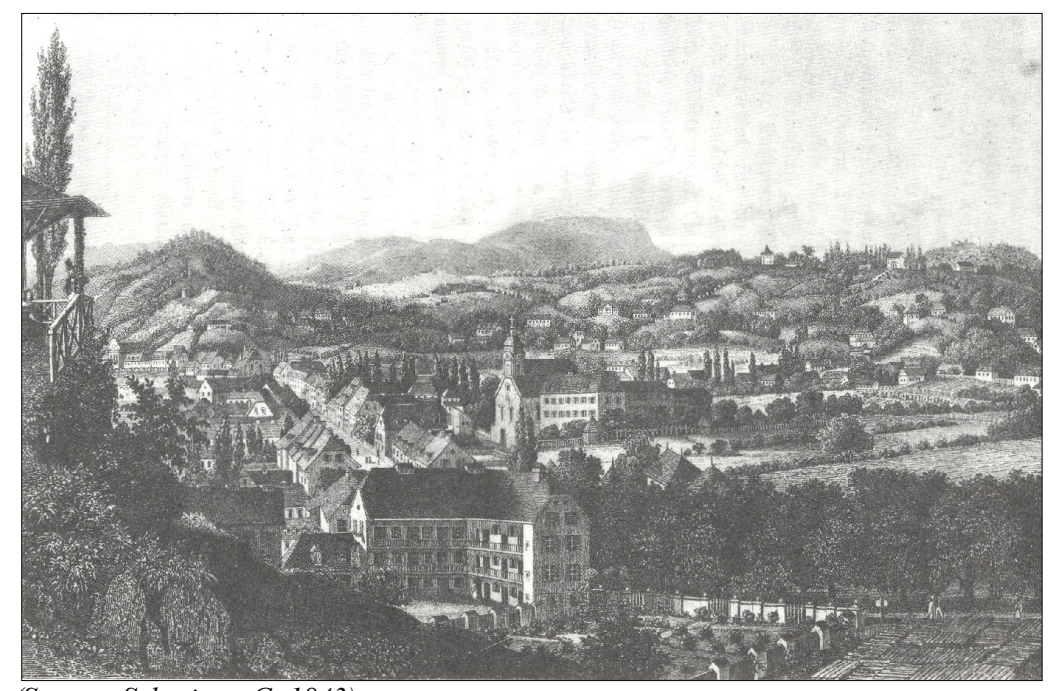

(Source: Schreiner, G. 1843).

\section{IMPACTS ON THE HISTORIC ROOFSCAPE}

The integrated aspect of a homogeneous roofscape can best be proofed when viewed from elevated observation points like the central Schloßberg (castle mountain) or from one of the surrounding hills of the city.

The most disturbing impacts on the roofscape of the pre-twentieth-century urban complex result from lacking or new regulations concerning the number of floors and the hight of construction in the local development plans. The period of economic growth and reconstruction after World War II has fortunately not that much affected the medieval core of Graz, yet it has left its footprints in the adjacent quarters of the founders' period. Several single high-rise-buildings have been constructed during the sixties and seventies, legalized by then existing building regulations and building permits (see Elisabethstraße, Grießplatz, Kärntnerstraße, etc., Fig. 4). 
Figure 4: Graz. Hugo-Wolf-Gasse. Single high-rise building amidst an ensemble from the founders'period

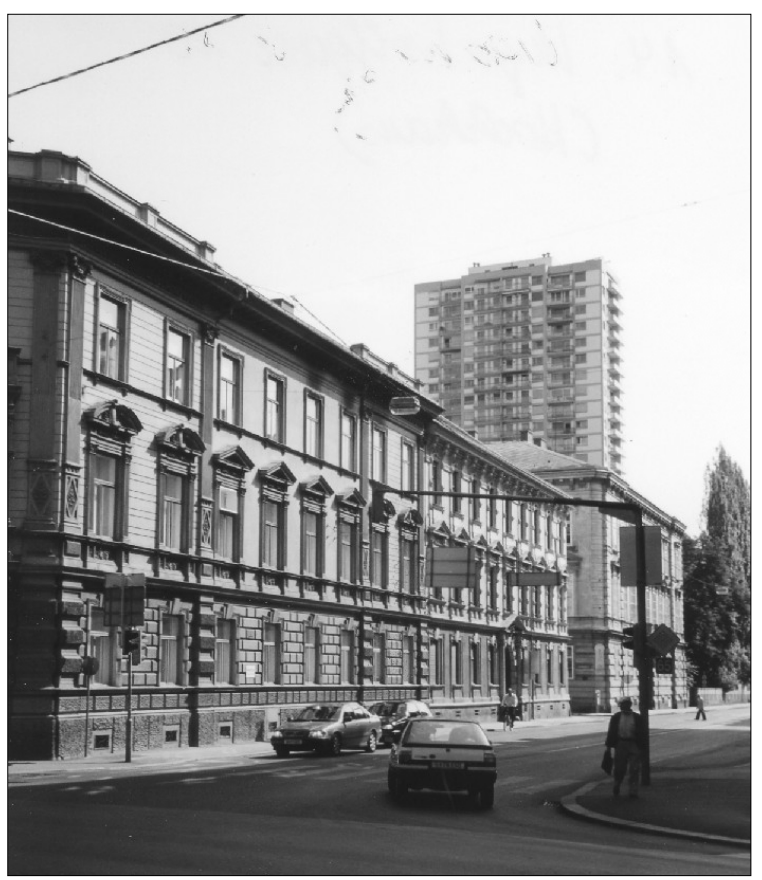

(Source: Ch. Müller, 2002).

These objects massively destroy the hitherto unbroken and even surface structure of the city. We can understand the 1974 Law for the Conservation of the Historic Center of Graz and its successive spatial extensions of 1979 (Zone III) and 1982 (Zone IV) as a reaction to this threat. Among the most decisive criteria for the establishment of special urban protection zones was the public interest in conserving urban architectonic and spatial structures that deserved protection because of their singular image, closed appearance, and their historic and/or architectonic pecularity.

Although the Conservation Law in many cases meets the requirements of an Act for the Protection of Ancient Monuments both acts differ substantially from each other: whereas the latter is more restrictive and focuses on the protection of monuments representing a high historic, cultural, or artistic value the aforementioned one is primarily a complex of provisions of substantive law comprising of different areas of interest like building codes, trade- and-industry law, transportation-law, financial-law, but also sociological, functional, medical or aesthetical aspects (conservation of typical and unique images of streets, places, or architectonic ensembles including parks, gardens, water courses, ponds, fences, urban street-furnishings like benches, advertising signs, flower-troughs, etc.).

Renovation, reconstruction, even demolishion and new construction of buildings, if necessary, under the Conservation Law is possible following the principle of saving and conserving the good heritage from the past as well as being open to modern and future 
developments. The roofscape of the historic center of Graz underlines this statement by the example of the new art center (Kunsthaus) on the river Mur, designed for the year of the cultural capital of Europe Graz 2003. It was planned by the British architects Cook and Fournier and contrasts with its blue, synthetic fibre bubble strongly with the surrounding red tile-roofs.

Shape, inclination and roofing materials usually follow certain regulations, customs, traditions, functional, economic and aesthetic considerations. Thus modifications of existing roofscapes demand a very sensitive line of action. In accordance with this requirement the Styrian Provincial Government in 1986 has issued an ordinance for the conservation of the roofscape in the protected area of the historic center of Graz. Its most important regulations are as follows (Mally K.-H. und Widtmann, H., 1986):

Inside the zone of protection the traditional image of the roofscape must be preserved in case of opening or structurally changing roofs. The roofscape in the above sense includes all formative features of a roof, like size, shape, construction, inclination, cornices, eaves, roofing material, colour of roof and superstructures (attics, dormers, chimneys, antennas, etc.) as well as the mergence of different roofs.

The visibility of the roofscape from public and open spaces on the ground (streets, places, backyards), from the castle hill and from surrounding observation points is of crucial interest.

Superstructures and installations for illumination purposes should be constructed as separate objects.

Above and below dormer windows an unsegmented strip of the roof should be preserved. On steep roofs (more than $45^{\circ}$ ) dormers should be equipped with lean-to roofs.

Tin roofs are tolerated in case of constructive necessity. Their colour has to be in conformity with that of their surroundings.

- No building permission shall be granted in the following cases:

- For flat roofs except from subordinate annexes in zone I.

- For other than clay tiles for new roofs in zone I.

- In case of new roofing in zone II and other zones that does not comply with the roofscape of the surrounding ensemble.

- For large-scale roofing elements provided they are not in accordance with their neighbourhood.

- For asymmetric roofings.

- For dormers of irregular shape and size depending on their visibility.

- For more than two rows of dormers one upon the other.

- For dormers which do not follow the rhythm of rafters or window-axis.

- In case of catwalks for chimney sweeps.

All these regulations limit the possibilities of completing or transforming roof-floor-spaces for residential purposes within protected areas. This can provoke conflicts between houseowners, architects, tenant's associations, real estate brokers, and flat hunters on the one side and public housing authorities, monument protection authorities and local planning boards on the other side. 
Flats on roof-floors except from mansards and penthouses like those in cellars usually were rated as substandard. This image has completely changed during the recent past when empty roof spaces have been increasingly demanded.

The development of flats, attics or penthouses on empty roof-floors, if properly executed offers special qualities of living to the users: a dramatic view over the city, plenty of light, higher air quality, lower noise immissions and (sometimes) even the possibility to lay out a roof garden. Through the formative integration of the roof truss into the spatial design of the flat new, unaccustomed levels of aesthetic perception are disclosed. On the other hand any interference into existing building substance requires a prudent and respectful adaptation to the circumstances (Fechner, J., 2002). Many architects today are very sceptical about the conversion of roof spaces into flats because of constructive difficulties (statics of the roof truss, thermal insulation, sanitary installation work, construction of elevators, etc.)

This statement is not only true to interior finishings of roof spaces but also to changes of their outer appearance. To avoid harm and high costs of undoing damages precise building consultation, perfect structural-physical planning and finishing must be demanded (s. Rau, O. und Braune, U., 1985).

One of the then most controversial projects of roof-space development in Graz for accommodation supply was that of K. Kada from 1986. The project affected two historical buildings from the founders' period in protection zone II (Fig. 5). The symmetric objects are facing the city park on a sensitive corner. Their original four stories should have been piled up by two additional stories which would have been a massive impact on the hight and roof-structure of the historic center. Finally a reasonable solution could be achieved. The new two stories were integrated into the existing roof retaining much of the character of the former shape of the roof. The architect respected the adjacent roofscape without renouncing the building period of his project. The idea to connect the roof-floors of the two buildings by a bridge made of steel and glass was rejected finally. The architect also found a remarkable answer for solving the difficult problem of how to attractively structure the forms of the roof corners.

In the years 1991-92 twelve new flats and additional office space had been accomplished on the roof-floor of this house. Since most of the rafters were rotten a completely new woodwork of the roof had to be constructed. For illuminating the flats the architect has chosen transparent and light dormers of steel and glass.

Other forms of dormers can be argued about from (Fig. 6) because of their spatial vicinity which allows to discuss the pros and cons of various types and their impact on the roofscape as a whole. The homogeneous impression can be substantially disturbed or even destroyed by an unorganic design of roofs especially if they can easily be viewed from the street level or from above (Architektur Aktuell, 1993).

The usage of roof spaces for residential purposes today very often is the only possibility of creating new flats in a historic center as namely in the period after World War II a heavy economic, social and functional transformation process has been taking place which needs no further explanation. Yet, being involved in the transformation and adaptation process of roof floors on historic sites today architects are specially challenged since they 
not only have to fullfill the needs and wishes of their clients but, moreover, those of monument protectors, of the local building inspection including Commissions for the Conservation of Historic Centers and municipal planning boards. Reconciling conflicting opinions that may arise from these various decision making institutions is a time-, money- and nerve-straining task.

Figure 5: Graz. Glacisstrasse. New mansard-roof over two stones by Klaus Kada on a house from the founders ' period

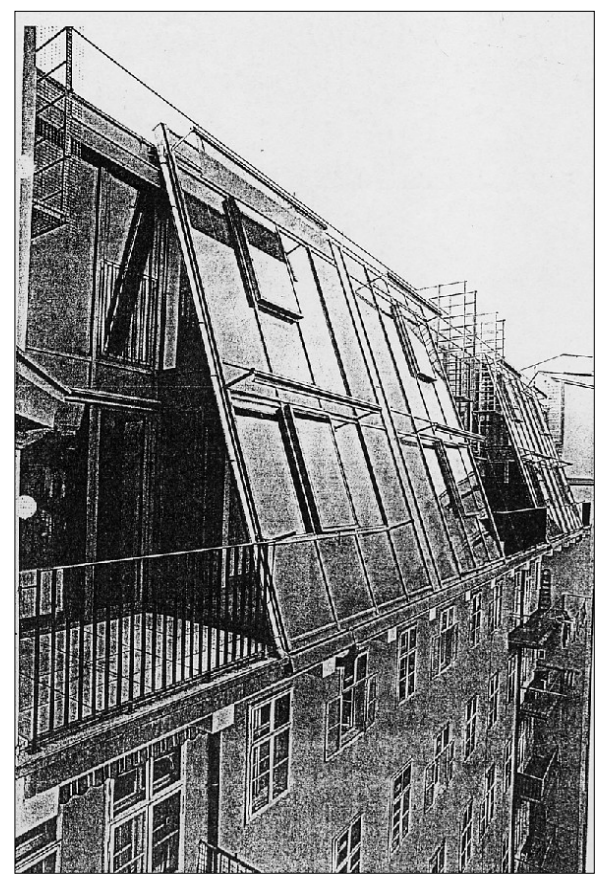

(Source: Ch. Müller, 2002).

The usage of roof spaces for residential purposes today very often is the only possibility of creating new flats in a historic center as namely in the period after World War II a heavy economic, social and functional transformation process has been taking place which needs no further explanation. Yet, being involved in the transformation and adaptation process of roof floors on historic sites today architects are specially challenged since they not only have to fullfill the needs and wishes of their clients but, moreover, those of monument protectors, of the local building inspection including Commissions for the Conservation of Historic Centers and municipal planning boards. Reconciling conflicting opinions that may arise from these various decision making institutions is a time-, money- and nerve-straining task.

Other possibilities to create additional living space for permanent dwellers in historic centers without severe interference with protected or traditional architecture are rare. One is rising the roof level by adding one or more stories to existing structures. This approach was 
preferred from the seventies through the eighties of the last century. It had led to some heavy discussions with art-historians and monument protectors especially about the question whether the structural alterations should be visible or concealed.

Figure 6: Graz. Roofscape around the Hauptplatz (main square) (Source: Ch. Müller, 2002).

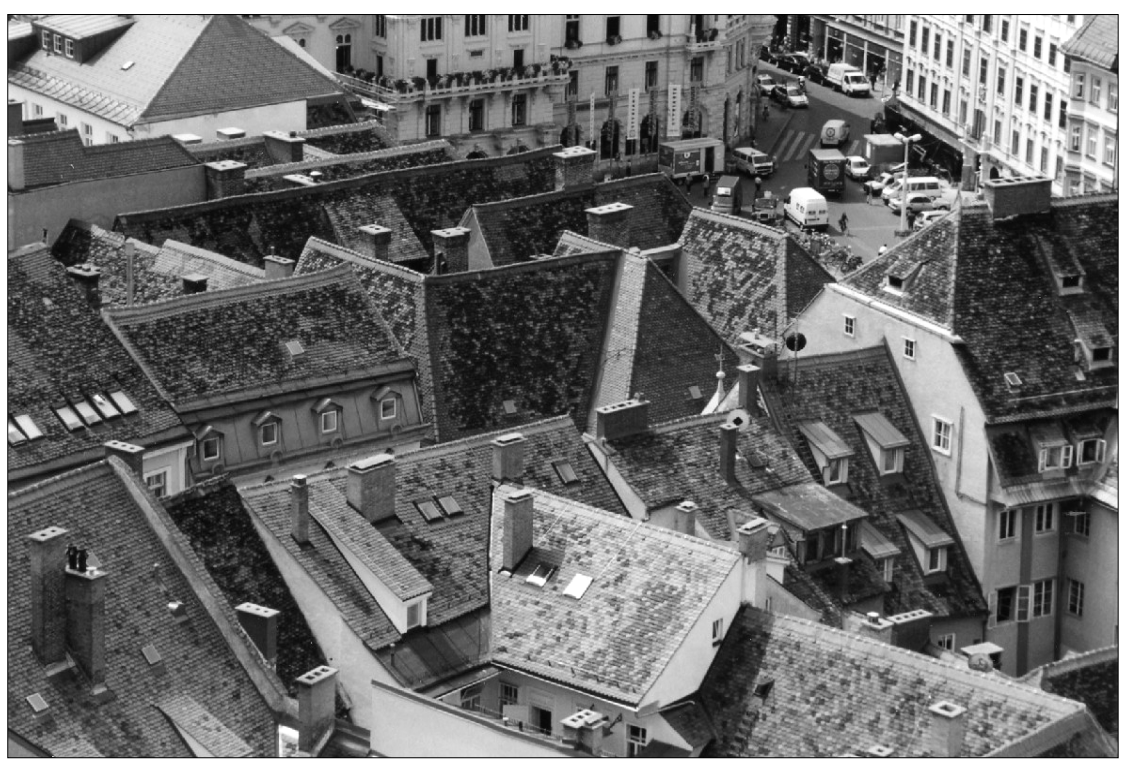

This dispute was newly inflamed in the recent past on some controversial extension works concerning roof floors of historic buildings within the conservation area. It centers around the never ending debate on how to build new within a historic environment (cf. ISG Magazin 3/2002 "Neues Bauen in alter Umgebung", ISG Magazin 4/2002). Without continuing this discussion the most frequent formal solutions of new construction (or urban renewal) which can also be found in Graz shall be mentioned:

1. adaptation to the style of the neighbouring architecture. In this case visible disturbances of the outward shape of a historic ensemble are not to be expected. The question is, however, whether this kind of architecture is creative and true,

2. conservation of historic facades only whereas the rest of the old building is subject to a completely new construction,

3. true copies of historic buildings. They are perhaps the easiest way to avoid protests from citizens or populistic politicians, yet copies can never replace the original in an artistic sense,

4. modern, qualitative, contemporary architecture often deliberately contrasting with its historic environs which very often provokes the public, and

5. contemporary but unpretentious (low quality) construction. Unfortunately this kind of solution is rather common since it usually enrages only good architects and, erroneously, is appraised cost-effective. 
Similar discussions cannot be avoided but, perhaps, emotions could be calmed down a bit if people were aware of the fact,that cities and towns as living organisms from their very beginning are subject to change. They are never complete. Their past, present and future shape is the result of continuous (new) construction, restauration, renovation, and demolishion. This is true for the whole as well as for the detail. Proceeding from the existing structures (e.g. of the roofscape) decisions should be sought which follow at least four criteria: social, ecological, functional, and formative demands (cf. Stadtverwaltung Bautzen, 2002).

Investigating urban roofscapes geographically, nevertheless, demands a multidisciplinary approach and rises many questions which stretch beyond the criteria mentioned above.

From a social point of view the historic center of Graz suffers from depopulation, overaging of the population, predominance of low house hold sizes (especially singles), of socially and economically weak persons, low standard housing and living conditions which, as commonly known, has resulted in expelling the residential population and small scale industries or craftsmen from the center and replacing their flats or workshops by institutions of the tertiary or quaternary sectors. There are only few possibilities to stop this trend. The construction of new tenements and apartment buildings is limited due to lack of adequate development sites, extremely high real-estate prizes and high competition for disposable sites in the center. Building regulations and local development plans are further obstacles. That is one reason why empty roof spaces in the historic core of cities increasingly gained interest from investors because they offered a rare and often the only opportunity of creating new living space in the city center. The idea of adapting roof spaces for dwelling purposes did not only meet the interests of the city councils who strove at stabilizing the residential population of the city but also new trends on the urban real-estate market.

Upperstory and roof-story flats, apartments or penthouse apartments became the ultimate in urban luxury living. Together with an increasing desire to live in the city for proximity of work and entertainment they are very popular with a higher income, middle-aged social group. Problems for the new dwellers and for urban authorities may arise from lacking permanent parking lots in close vicinity to the residences.

The creation of new living space under roofs gives the (partly) redevelopment of the functional structure of historic centers a chance. It should be used as an alternative whenever possible as long as it respects the formative demands in shaping the traditional roofscape which belongs to the urban historic heritage and, therefore, deserves our special attention and care.

\section{SUMMARY}

When the historic center of Graz has been awarded the state of a world cultural heritage in 1999 and Graz was elected the European cultural capital for 2003 it was also on behalf of its unique medieval roofscape. The social and economic changes which had affected the city center after World War II, however, increasingly have endangered this architectonic treasure. The demand for more office space and expanding commercial activities together with new socio-demographic realities have contributed to a heavy decline of the residential 
population in the old town of Graz. Lacking possibilities for and difficulties with constructing new multifamily residential accommodations in urban conservation areas as well as a growing demand for penthouse flats and apartments increased the pressure on the existing historic building structure. Additional commercial or living space could mainly be achieved in two ways: either by adding new stories to existing buildings or by adapting empty roof spaces. Both possibilities impair the traditional roofscape but what are the alternatives to complete ignorance of the architectonic heritage or its unconditional conservation?

The city of Graz and the provincial government of Styria reacted to these challenges already in 1974 when the Law for the Conservation of the Historic Center of Graz was approved and a special commission for its surveillance was installed. The commission's success so far is ambivalent.

The paper strives at drawing greater attention to this interesting topic. The investigation of the roofscape of Graz has reached only an initial status concentrating on its most visible and remarkable exterior changes first. Architectonic and economic problems, questions concerning construction law, building regulations, zoning, transportation, parking and standard of supplies available will be discussed later.

\section{References}

Architektur Aktuell. April 1993, 49-51.

Breitling, P.. 1982: In der Altstadt leben. Altstadterhaltung dargestellt am Beispiel Graz. Graz-Stuttgart, 199 pp.

Fechner, J., 2002: Altbaumodernisierung. Wien, 235 pp.

ISG Magazin (Int. Städteforum Graz). Heft 3/2002 und 4/2002. Graz.

Mally, K.-H. und Widtmann, H., 1996: Das Grazer Altstadterhaltungsgesetz 1980. Graz, $145 \mathrm{pp}$.

Müller, Ch., 2002: Physiognomische Struktur der Dachlandschaft der Grazer Altstadt. Dipl.Arbeit Naturwiss. Fak. Universität Graz. 123 pp.

Rau, O. und Braune, U., 1985: Der Altbau: Renovieren, Restaurieren, Modernisieren. Leinfelden-Echterdingen, $358 \mathrm{pp}$.

Schreiner, G. 1843 (1976): Grätz. (Ungekürzte Sonderausgabe) Graz, 570 pp.

Stadtverwaltung Bautzen (ed.), 2002: Stadterneuerung in Bautzen 1990-2001 Bautzen. 70p. 